ISSN 1412-2936

EISSN 2549-7308

\title{
Pengaruh Kepuasan Kerja dan Komitmen Organisasional Terhadap Kinerja Guru yang Dimoderasi oleh Organizational Citizenship Behavior (OCB) Di SMAN 1 Tilatang Kamang
}

\author{
Syukri Hidayat ${ }^{1}$ \\ ${ }^{1}$ Program Studi Magister Manajemen, Fakultas Ekonomi, Universitas Andalas Padang \\ Hendra Lukito ${ }^{2}$ \\ ${ }^{2}$ Program Studi Magister Manajemen, Fakultas Ekonomi, Universitas Andalas Padang
}

\begin{abstract}
ABSTRAK
Penelitian ini bertujuan untuk mengetahui dan menganalisis pengaruh kepuasan kerja dan komitmen organisasional terhadap kinerja dengan organizational citizenship behavior (OCB) sebagai variabel moderasi pada guru di SMAN 1 Tilatang Kamang. Penelitian ini merupakan penelitian explanatory dengan metode kuantitatif. Teknik pengambilan sampel dilakukan dengan teknik sensus, dengan jumlah sampel 57 guru. Penelitian ini menggunakan Partial Least Squares - Structural Equations Modeling (PLS-SEM) dengan program smartPLS 3. Hasil penelitian menunjukkan bahwa kepuasan kerja berpengaruh positif signifikan terhadap kinerja, komitmen organisasional berpengaruh positif signifikan terhadap kinerja, Organizational Citizenship Behavior (OCB) tidak memoderasi kepuasan kerja dan komitmen organisasional terhadap kinerja guru di SMAN 1 Tilatang Kamang.
\end{abstract}

Kata Kunci:Kepuasan Kerja, Komitmen Organisasional, Organizational Citizenship Behavior (OCB), Kinerja

\section{ABSTRACT}

This study aimed to examine and analyze the effect of job satisfaction and organizational commitment with Organizational Citizenship Behavior (OCB) as moderating variable toward teachers in SMAN 1 Tilatang Kamang. This study was explanatory research and used quantitative method. The sampling technique was census method and the sample size was 57 samples. The data was analyzed by using Partial Least Squares - Structural Equations Modeling (PLS-SEM) and smartPLS application. The result showed job satisfation had positive significant correlation with teacher performance, organizational commitment had positive significant correlation with teacher performance, organizational citizenship behavior not moderate job satisfaction and organizational commitment toward teacher performance in SMAN 1 Tilatang Kamang.

Keywords:Job Satisfaction, Organizational Commitment, Organizational Citizenship Behavior, Performance

\section{PENDAHULUAN}

Dalam melaksanakan peran didunia pendidikan, sekolah dituntut untuk mampu mengatasi berbagai hambatan. Beragamnya kualitas input, berjalannya proses pendidikan dan pengajaran serta upaya mempertahankan atau meningkatkan mutu lulusan adalah beberapa hal yang harus dan senantiasa menjadi tantangan yang besar yang harus ditaklukkan.

Kemajuan suatu bangsa tidak 
ISSN 1412-2936

EISSN 2549-7308

terlepas dari kualitas sumber daya manusia yang dimiliki oleh bangsa tersebut. Baik buruknya kualitas sumber daya manusia menjadi tolak ukur dari majunya perkembangan suatu bangsa. Kualitas sumber daya manusia yang ada dipengaruhi oleh baik tidaknya sistem pendidikan yang ada. Pendidikan dengan mutu yang baik akan mampu melahirkan sumber daya manusia yang kompeten dan mampu bersaing, baik dalam tingkat nasional maupun internasional.

Indonesia sendiri, dalam laporan indeks sumber daya manusia atau Human Capital Index $(\mathrm{HCl})$ yang dikeluarkan oleh World Bank pada bulan Oktober 2018 berada pada peringkat 87 dari 157 negara (Worldbank.org). Secara garis besar, indeks sumber daya manusia menjadi barometer untuk melihat kebijakan pemerintah yang memastikan kesehatan dan pendidikan penduduknya berbanding lurus dengan potensi masyarakatnya sebagai angkatan kerja dimasa depan. Dalam penjelasannya, World Bank menyebutkan, indeks sumber daya manusiamuncul dalam rentang antara nilai 0 sampai 1 . Semakin tinggi nilai suatu negara mendekati angka 1 , maka produktivitas penduduknyaberada dalam kinerja yang sangat tinggi dengan didukung oleh lingkungan yang sehat dan pendidikan yang baik.

Pada tahun 2016, Pusat data dan Statistik kementerian Pendidikan dan Kebudayaan Republik Indonesia menerbitkan laporan tentang sumber daya manusia pada tingkatan Sekolah Dasar dan Sekolah Menengah di Indonesia. Dalam laporannya, secara umum kinerja kepala sekolah dan guru sekolah di Indonesia masih tergolong rendah.

Berdasarkan tabel 1.1 maka dapat dilihat bahwa kinerja Kepala Sekolah Guru sebesar 77,69 termasuk kategori kurang. Kinerja Kepala Sekolah Guru (KSG) Sekolah Menengah Atas adalah satu-satunya tingkatan pendidikan yang mendapatkan penilaian Pratama dengan nilai sebesar 81,16 . Sedangkan tingkatan pendidikan lainnya berada termasuk kategori kurang. Kemudian untuk kinerja Kepala Sekolah (KS), Kepala Sekolah Sekolah Luar Biasa (SLB) mendapatkan penilain terendah dengan nilai sebesar 73,93 dan termasuk kedalam kategori kurang. Untuk penilaian kinerja Guru (G), guru pada satuan pendidikan Sekolah menengah atas mendapatkan nilai sebesar 80,84 dengan kategori pratama dan guru Sekolah Luar Biasa (SLB) mendapatkan nilai terendah sebesar 74,83 dan termasuk kedalam kategori rendah. Sehingga dapat disimpulkan bahwa kinerja dari Kepala sekolah dan guru untuk satuan Sekolah Dasar dan Menengah di Indonesia masih berada dalam kategori rendah. Disamping itu, Indonesia juga masih kekurangan tenaga guru sebanyak 146.987 orang.

Keberhasilan lembaga pendidikan dalam mewujudkan mencapai kinerja yang tinggi itu sendiri sangatlah ditentukan oleh kualitas sumber daya yang dimiliki oleh sekolah tersebut. Seringkali dikatakan bahwa kinerja yang baik dari guru tergantung pada keefektifan dalam mengajar. Sebagai tenaga profesional, guru dipercaya sebagai kelompok profesional yang paling penting dalam perkembangan siswa yang belajar disekolah tersebut. Cheng dalam Slamet (2013) menjelaskan bahwa kinerja guru dapat dipengaruhi oleh kepuasan kerja, komitmen terhadap pekerjaan, job meaningful dan tanggung jawab pekerjaan. Ketika individu merasa puas terhadap pekerjaan, komitmen akan meningkat dan karyawan juga cenderung lebih berkomitmen terhadap organisasi (Claire,2017; Samiya,2010; Inuwa,2016).

Kepuasan kerja merupakan salah satu faktor penting yang mempengaruhi kinerja karena sebagian besar waktu manusia dihabiskan ditempat kerja. Kepuasan kerja menurut Gibson (2000) adalah suatu sikap yang dimiliki individu mengenai pekerjaannya. Sedangkan Erwin dalam Yadewani mendefenisikan kepuasan kerja sebagai perasaaan karyawan terhadap pekerjaannya, dimana 
ISSN 1412-2936

EISSN 2549-7308

perasaan itu dapat berupa favourable, namun juga bisa bersifat unvafourable, tergantung dari bagaimana karyawan menilai aspek-aspek kepuasan kerja itu sendiri. Kreitheraan (2001) juga menjelaskan bahwa kepuasan kerja merupakan sikap emosional yang menyenangkan dan mencintai pekerjaan, sikap ini tercermin pada moral kerja, kedisiplinan dan prestasi kerja. Kepuasan kerja adalah yang dinikmati dalam pekerjaan dengan memperoleh hasil kerja, penempatan perlakuan, peralatan, dan suasana lingkungan kerja yang baik.Selain itu, Sekolah juga harus terus berusaha menciptakan lingkungan yang baik dan perasaan yang positif terhadap organisasi untuk meningkatkan kinerja, sehingga dapat memberikan kepuasan kerja bagi guru dan tenaga kependidikan. Nimalathasan \&Barbeta (2010) menjelaskan manfaat yang didapat dari kepuasan kerja, yaitu dapat mengurangi moral stress, menciptakan ide-ide dan inovasi baru yang dapat membantu karyawan mencapai level yang lebih tinggi, hubungan yang baik, pemikiran yang fresh dengan pimpinan dan kolega.

Selanjutnya, faktor lain yang mempengaruhi kinerja adalah komitmen organisasional. Rwinert, Maciel dan Candatten (2011) mendefenisikan komitmen organisasional sebagai penciptaan keunggulan kompetitif secara umum untuk mengidentifikasi peran individu dalam organisasi sebagai sumber daya saing organisasi. Hal ini diperkuat oleh penelitian yang dilakukan oleh Zefeiti dan Mohamad (2017) bahwa komitmen organisasional berpengaruh terhadap kinerja karyawan. Dalam suatu organisasi sekolah, guru dituntut untuk terus memperbaiki kinerjanya, baik secara individu, kelompok maupun organisasi. Guru yang memiliki komitmen yang tinggi akan memberikan usaha yang maksimal secara sukarela untuk kemajuan sekolah, berpartisipasi dan terlibat aktif dalam memajukan sekolah dan menjalankan tugas yang diberikan kepadanya.
Salah satu sekolah yang ada di kabupaten Agam adalah Sekolah Menengah Atas Negeri (SMAN) 1 Tilatang Kamang dengan visinya yaitu terwujudnya insan yang sehat, cerdas, kreatif, inovatif, berakhlak mulia dan berwawasan. SMAN 1 Tilatang Kamang sendiri memiliki 57 guru dan 12 orang tenaga kependidikan. Berdasarkan wawancara penulis dengan kepala sekolah, SMAN 1 Tilatang Kamang, dalam 3 tahun terakhir mencapai prestasi yang baik, mulai pada tingkat Kabupaten hingga Nasional.

Prestasi SMAN 1 Tilatang Kamang yaitu juara 1 sekolah Sehat tingkat kabupaten Agam, juara 2 tingkat provinsi, sekolah Adiwiyata tingkat kabupaten Agam (2014), tingkat provinsi Sumatera Barat (2015),dan Nasional (2016). Pada tahun 2018, SMAN 1 Tilatang Kamang terpilih sebagai sekolah model pelaksana program kewirausahaan yang dinaungi oleh Dirjen Pendidikan Tinggi Nasional. SMAN 1 Tilatang Kamang menjadi satusatunya sekolah yang terpilih di kabupaten Agam. Tujuan dari program ini adalah untuk melatih jiwa enterpreneurship siswa berupa latihan, praktek dan bazar.

Disamping melihat capaian dari sisi non akademis SMAN 1 Tilatang Kamang, tentu juga perlu diperhatikan capaian dari sisi akademis siswa yang belajar di sekolah tersebut. Pencapaian dibidang akademik dapat dilihat dari jumlah lulusan yang melanjutkan pendidikan ke tingkat perguruan tinggi negeri dan swasta. Pencapaian ini tentunya adalah hal yang baik sebagai hasil kerjasama dari seluruh lapisan sekolah, termasuk kepala sekolah, guru dan tenaga kependidikan di sekolah tersebut.

Guru merupakan tenaga pendidik profesional dengan tugas utama mendidik, mengajar, membimbing, mengarahkan, melatih, menilai dan mengevaluasi peserta didik. Sebagai pengajar, guru bertugas mengajarkan sejumlah bahan pengajaran kepada 
ISSN 1412-2936

EISSN 2549-7308

peserta didik agar menjadi manusia yang susila, kreatif dan mandiri (Undangundang nomor 14 tahun 2005 pasal 1 ayat 1). Selain itu, terdapat kegiatan lain yang harus dijalankan oleh guru, seperti menjadi panitia kegiatan sekolah, menghadapi kenakalan peserta didik, dan lain sebagainya. Seringkali pekerjaan harus dilakukan diluar jam kerja, yang berarti pula bahwa pekerjaan yang kompleks yang membutuhkan dedikasi yang tinggi, perilaku bertanggung jawab, kemauan untuk membantu dan inisiasi untuk turut serta dalam melakukan pekerjaan tambahan. Kondisi ini temasuk kedalam komponen organizational citizenship behavior (OCB). Organizational Citizenship Behavior (OCB) menurut Organ (1998) adalah perilaku individu yang bebas yang tidak berkaitan secara lansung atau eksplisit dengan sistem reward secara formal dan dapat meningkatkan keefektifan fungsi organisasi. Organizational citizenship behavior bersifat bebas dan sukarela, karena perilaku tersebut tidak diharuskan dalam persyaratan kerja atau job deskripsi, melainkan ini adalah pilihan personal seseorang. William dalam Bogler (2005) menjelaskan bahwa OCB terbagi menjadi dua, yaitu OCB-I dan OCB-O. OCB-I adalah sikap yang berhubungan dengan individu yang secara tidak lansung memberikan kontribusi terhadap organisasi. Contohnya adalah guru yang menyediakan waktu tambahan untuk membantu siswa meningkatkan kemampuan belajarnya atau membantu rekan kerja yang punya banyak tugas. Sedangkan OCB-O adalah perilaku yang memberikan manfaat kepada organisasi secara keseluruhan. Contohnya adalah guru yang secara suka rela melakukan tugas tanpa dibayar, atau juga memberikan ide ataupun saran meningkatkan sekolah.

\section{METODE}

Penelitian ini merupakan penelitian explanatory karena bertujuan untuk memperoleh pengertian mengenai fenomena yang diteliti dan melengkapi pengetahuan lewat pengembangan teori lebih lanjut dan pengujian hipotesis (Sekaran,2011:100). Penelitian ini dilakukan dengan metode kuantitatif, menggunakan analisis statistik untuk melakukan pengujian secara empiris hubungan antar variabel penelitian.Penelitian ini dilakukan di SMAN 1 Tilatang Kamang, di Pekan Kamis Kecamatan Tilatang Kamang, Kabupaten Agam. Pengumpulan data penelitian dilakukan pada bulan April 2019 dengan sampel seluruh guru di SMAN 1 Tilatang Kamang yang berjumlah 57 orang.

Sumber data yang digunakan adalah data primer dan data sekunder yang diperoleh secara langsung dari SMAN 1 Tilatang Kamang melalui wawancara dan survei kuesioner penelitian kepada responden penelitian dan data yang diperoleh secara tidak langsung diantaranya melalui studi kepustakaan, jurnal internasional, buku teks, internet, serta sumber lain yang relevan dan dapat dijadikan referensi dalam penelitian.Bentuk item kuesioner yang digunakan dalam variabel yang diteliti diberi bobot atau skor yaitu Sangat Setuju (SS) dengan skor 5, Setuju (S) dengan skor 4, Netral (N) dengan skor 3, Tidak Setuju (TS) dengan skor 2, dan Sangat Tidak Setuju (STS) dengan skor 1(Sekaran, 2006).

Variabel dalam penelitian ini terdiri dari variabel terikat yaitu kinerja, sedangkan variabel bebasnya adalah kepuasan kerja dan komitmen organizational serta variabel moderasinya adalah organizational citizenship behavior (OCB). Teknik analisis data yang digunakan berupa analisis deskriptif dan analisis data statistik inferensial. Statistik deskriptif dalam penelitian ini antara lain: penyediaan data dalam bentuk tabel, grafik, perhitungan median, mean, standar deviasi, perhitungan persentase dan TCR (Sekaran, 2006). Data tersebut berasal dari jawaban yang diberikan oleh 
ISSN 1412-2936

EISSN 2549-7308

responden atas item-item yang terdapat dalam kuesioner. Selanjutnya, penelitian akan mengolah data dengan menggunakan Microsoft Office Excel 2007 dan diolah dengan aplikasi PLS dan kemudian diberi penjelasan. Ridwan
(2006) menjelaskan bahwa untuk mengetahui Tingkat Capaian Responden (TCR) dari setiap deskriptif variabel, maka digunakan rumus sebagai berikut:

$$
\mathrm{TCR}=\frac{\text { Skor Total }}{5}
$$

Tabel 1. Tingkat Capaian Responden

\begin{tabular}{ccc}
\hline No. & Kategori Jawaban & Interval Jawaban \\
\hline 1 & Sangat Tinggi & $81-100$ \\
\hline 2 & Tinggi & $66-80.99$ \\
\hline 3 & Rendah & $55-65.99$ \\
\hline 4 & Sangat rendah & $0-54.99$ \\
\hline Sumber : Atmaja (2010) & &
\end{tabular}

Analisis data statistik inferensial diukur dengan menggunakan software SmartPLS mulai dari pengukuran model (outer model), struktur model (inner model) dan pengujian hipotesis (Ghozali, 2015). PLS menurut Ghozali (2015), merupakan pendekatan alternatif yang bergeser dari pendekatan Structural Equation Modelling (SEM) berbasis kovarian menjadi basis varian. SEM yang berbasis kovarian umumnya menguji kualitas atau teori, sedangkan PLS lebih bersifat predictive model. PLS merupakan metode analisis yang powerful, tidak harus memenuhi syarat asumsi normalitas data dan ukuran sampel tidak harus besar. PLS selain dapat digunakan untuk membangun hubungan yang belum ada landasan teorinya atau untuk menguji proposisi.

$$
\text { Langkah-langkah pengujian }
$$

dilakukan dalam penelitian ini adalah pertama evaluasi measurement model yang terdiri dari uji individual item reliability, uji internal Consistency, dan uji discriminant validity, kedua evaluasi structural model dengan Pemeriksaan terhadap model struktural dilakukan dengan melihat nilai R- square, dan yang ketiga pengujian hipotesis yang dilakukan dengan pengujian Variance-based SEM atau Partial Least Square (SEM-PLS) dengan program warp pls 3.0. SEM-PLS digunakan untuk penelitian yang bersifat eksplorasi. Dengan kata lain , pendekatan PLS cocok digunakan untuk tujuan prediksi (Solihin, 2013).

\section{HASIL DAN PEMBAHASAN}

\subsection{Hasil}

\subsubsection{Respond Rate}

Penelitian ini dilakukan pada guru di SMAN 1 Tilatang Kamang dengan metode survei. Dalam penelitian ini, guru sebagai responden diberikan kuesioner yang bersifat tertutup dengan skala likert untuk dilakukan pengisian secara langsung. Kuesioner tersebut bersifat rahasia sehingga guru diharapkan melakukan pengisian secara jujur dan independen. Dari 57 kuesioner yang telah didistribusikan, maka tingkat respon

\begin{tabular}{|c|c|}
\hline Keterangan & Frekuensi \\
\hline Kuesioner yang disebarkan & 57 \\
\hline Kuesioner yang kembali & 57 \\
\hline Kuesioner yang tidak kembali & 0 \\
\hline Kuesioner yang layak diolah & 57 \\
\hline Respond Rate & $100 \%$ \\
\hline Sumber :Hasil Distribusi Kuesioner & \\
\hline
\end{tabular}
penelitian sebagai berikut. 
ISSN 1412-2936

EISSN 2549-7308

tersebut dengan melakukan pengisian secara lansung. Berdasarkan data terebut, diketahui bahwa tingkat respond rate dalam penelitian ini sebesar $100 \%$. Hal ini membuktikan bahwa guru di SMAN 1 Tilatang Kamang sangat kooperatif menjadi sampel dalam penelitian ini.

Tabel 3. Demografi Responden

\subsubsection{Deskripsi Demografi Responden}

Data demografi responden diproses dengan menggunakan Microsoft office excel 2007 dan diolah dengan aplikasi SPSS versi 22.00.Dari hasil tersebut dapat dijelaskan gambaran umum responden yang ikut berpartisipasi dalam pengisian kuesioner penelitian ini.

\begin{tabular}{llcc}
\hline Demografi & Deskripsi & Frekuensi & Persentase (\%) \\
\hline \multirow{2}{*}{ Jenis Kelamin } & LakiLaki & 8 & 14 \\
\cline { 2 - 4 } & Perempuan & 49 & 86 \\
\hline & $<25$ Tahun & 1 & 1.8 \\
\cline { 2 - 4 } & 26-30 Tahun & 2 & 3.5 \\
\cline { 2 - 4 } & 31-35 Tahun & 2 & 3.5 \\
\cline { 2 - 4 } 36 - 40 Tahun & 2 & 3.5 \\
\cline { 2 - 4 } & $>40$ Tahun & 50 & 87.7 \\
\cline { 2 - 4 } & SMA / SLTA & 0 & 0 \\
\cline { 2 - 4 } & D3 & 2 & 3.5 \\
\cline { 2 - 4 } & S1 & 53 & 93 \\
\hline Lama Bekerja & $<3$ Tahun & 0 & 1.8 \\
\cline { 2 - 4 } & 3-5 Tahun & 56 & 0 \\
\cline { 2 - 4 } & $>5$ Tahun & 54 & 98.2 \\
\hline Status Pekerjaan & PNS & 3 & 94.7 \\
\cline { 2 - 4 } & Honorer & 56 & 5.3 \\
\hline Status Pernikahan & Menikah & 1 & 1.8 \\
\cline { 2 - 4 } & Belum Menikah & &
\end{tabular}

Sumber: Hasil Olahan Data, 2019

Responden yang berjenis kelamin perempuan terlihat paling banyak berpartisipasi dengan persentase sebesar $86 \%$ sedangkan sisanya adalah responden berjenis kelamin laki-laki dengan persentase sebesar 14\%. Sedangkan apabila dilihat dari umur responden, rentang umur $>40$ tahun adalah yang terbanyak dengan persentase sebesar $87,7 \%$, umur 26 30 tahun dan 36 - 40 tahun sebesar 3,5 $\%$ dan sisanya tang terendah adalah $<25$ tahun sebesar $1.8 \%$.Selanjutnya adalah pendidikan yang ditempuh oleh responden, hampir keseluruhan responden berpendidikan $\mathrm{S} 1$ dengan persentase sebesar $93 \%$ dengan masa kerja > 5 tahun dengan persentase sebesar 98,2 \%. Hampir keseluruhan responden berstatus Pegawai Negri Sipil (PNS) dengan persentase sebesar 94,7 $\%$ dengan status menikah sebesar 98,2 $\%$.

\subsubsection{Deskripsi Variabel Penelitian}

Sebelum melakukan tahapan pengujian hipotesis lebih lanjut maka terlebih dahulu dilakukan deskripsi variabel untuk mengetahui tanggapan terhadap kepuasan kerja, komitmen organisasional, organizational citizenship behavior (OCB) dan kinerja padaguru di SMAN 1 Tilatang Kamang yang diperoleh dari penyebaran kuesioner penelitian. Jawaban responden atas variabel penelitian diproses menggunakan microsoft office excel 2007 dan diolah 
ISSN 1412-2936

dengan aplikasi SPSS versi 22.00 .

\subsubsection{Deskripsi Variabel Kinerja}

Dalam penelitian ini, kinerja merupakan variabel terikat yang mana terdiri dari dimensi task performance
EISSN 2549-7308

dengan 6 item pernyataan, dimensi contextual performance dengan 6 item pernyataan, dan dimensi adaptive performance dengan 6 item pernyataan.

Tabel 4. Deskripsi Variabel Kinerja

\begin{tabular}{|c|c|c|c|c|c|c|c|c|c|c|c|c|c|c|}
\hline \multirow[t]{2}{*}{ No. } & \multirow[t]{2}{*}{ Item } & \multicolumn{2}{|c|}{ SS } & \multicolumn{2}{|c|}{$\mathbf{S}$} & \multicolumn{2}{|r|}{$\mathbf{N}$} & \multicolumn{2}{|c|}{ TS } & \multicolumn{2}{|c|}{ STS } & \multirow[t]{2}{*}{$\mathbf{N}$} & \multirow[t]{2}{*}{ Mean } & \multirow[t]{2}{*}{ TCR } \\
\hline & & $\mathbf{F i}$ & $\%$ & $\mathbf{F i}$ & $\%$ & $\mathbf{F i}$ & $\%$ & $\mathbf{F i}$ & $\%$ & $\mathbf{F i}$ & $\%$ & & & \\
\hline \multicolumn{15}{|c|}{ Task Performance } \\
\hline 1 & $\begin{array}{l}\text { Saya } \quad \text { memiliki } \\
\text { standar kinerja yang } \\
\text { tinggi }\end{array}$ & 11 & 19,30 & 28 & 49,12 & 14 & 24,56 & 2 & 3,51 & 2 & 3,51 & 57 & 3,77 & 75,44 \\
\hline 2 & $\begin{array}{lr}\text { Saya } & \text { mampu } \\
\text { menangani } & \text { tugas } \\
\text { saya sendiri tanpa } \\
\text { banyak pengawasan }\end{array}$ & 8 & 14,04 & 25 & 43,86 & 19 & 33,33 & 3 & 5,26 & 2 & 3,51 & 57 & 3,60 & 71,93 \\
\hline 3 & $\begin{array}{l}\text { Saya bersemangat } \\
\text { dalam bekerja }\end{array}$ & 5 & 8,77 & 25 & 43,86 & 21 & 36,84 & 4 & 7,02 & 2 & 3,51 & 57 & 3,47 & 69,47 \\
\hline 4 & $\begin{array}{lr}\text { Saya tahu } & \text { bahwa } \\
\text { saya } & \text { dapat } \\
\text { menangani } & \text { banyak } \\
\text { tugas } & \text { untuk } \\
\text { mencapai } & \text { tujuan } \\
\text { sekolah } & \\
\end{array}$ & 9 & 15,79 & 21 & 36,84 & 22 & 38,60 & 3 & 5,26 & 2 & 3,51 & 57 & 3,56 & 71,23 \\
\hline 5 & $\begin{array}{l}\text { Saya menyelesaikan } \\
\text { tugas saya dengan } \\
\text { tepat waktu }\end{array}$ & 5 & 8,77 & 27 & 47,37 & 19 & 33,33 & 4 & 7,02 & 2 & 3,51 & 57 & 3,51 & 70,18 \\
\hline 6 & $\begin{array}{l}\text { Rekan-rekan saya } \\
\text { percaya bahwa saya } \\
\text { memiliki kinerja yang } \\
\text { tinggi di sekolah }\end{array}$ & 7 & 12,28 & 30 & 52,63 & 15 & 26,32 & 3 & 5,26 & 2 & 3,51 & 57 & 3,65 & 72,98 \\
\hline & Rata-Rata & 8 & 13,16 & 26 & 45,61 & 18 & 32,16 & 3 & 5,56 & 2 & 3,51 & 57 & 3,59 & 71,87 \\
\hline \multicolumn{15}{|c|}{ Contextual Performance } \\
\hline 7 & $\begin{array}{l}\text { Saya biasanya } \\
\text { memberikan bantuan } \\
\text { kepada rekan kerja } \\
\text { ketika diminta atau } \\
\text { dibutuhkan }\end{array}$ & 10 & 17,54 & 23 & 40,35 & 18 & 31,58 & 5 & 8,77 & 1 & 1,75 & 57 & 3,63 & 72,63 \\
\hline 8 & $\begin{array}{l}\text { Saya menyampaikan } \\
\text { simpati dan empati } \\
\text { kepada rekan kerja } \\
\text { ketika mereka dalam } \\
\text { kesulitan }\end{array}$ & 15 & 26,32 & 29 & 50,88 & 9 & 15,79 & 3 & 5,26 & 1 & 1,75 & 57 & 3,95 & 78,95 \\
\hline 9 & $\begin{array}{l}\text { Saya } \\
\text { berpartisipasi, aktif } \\
\text { berdiskusi dalam } \\
\text { kelompok dan rapat } \\
\text { kerja }\end{array}$ & 16 & 28,07 & 19 & 33,33 & 17 & 29,82 & 3 & 5,26 & 2 & 3,51 & 57 & 3,77 & 75,44 \\
\hline 10 & $\begin{array}{l}\text { Saya senang berbagi } \\
\text { ide dan pengetahuan } \\
\text { bersama tim saya }\end{array}$ & 15 & 26,32 & 21 & 36,84 & 15 & 26,32 & 4 & 7,02 & 2 & 3,51 & 57 & 3,75 & 75,09 \\
\hline
\end{tabular}


ISSN 1412-2936

EISSN 2549-7308

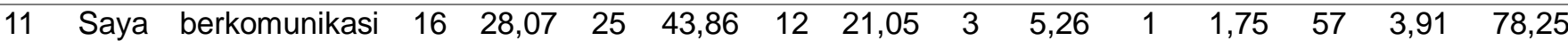
secara efektif dengan rekan-rekan saya untuk pemecahan masalah dan pengambilan keputusan

\section{Rata-Rata}

$\begin{array}{lllllllllllll}14 & 25,26 & 23 & 41,05 & 14 & 24,91 & 4 & 6,32 & 1 & 2,46 & 57 & 3,80 & 76,07\end{array}$

Adaptive Performance

Saya memiliki

12 kecerdasan mobilitas kolektif yang baik dalam kerja tim

Saya dapat mengelola perubahan

13 dalam pekerjaan saya dengan sangat baik setiap kali situasi $\begin{array}{lllllllllllll}15 & 26,32 & 20 & 35,09 & 14 & 24,56 & 4 & 7,02 & 4 & 7,02 & 57 & 3,67 & 73,33\end{array}$ menuntut hal tersebut

Saya selalu percaya bahwa saling

14 pengertian dapat mengarah pada solusi yang layak bagi sekolah

$\begin{array}{lllllllllllll}16 & 28,07 & 29 & 50,88 & 10 & 17,54 & 1 & 1,75 & 1 & 1,75 & 57 & 4,02 & 80,35\end{array}$

Saya sangat nyaman

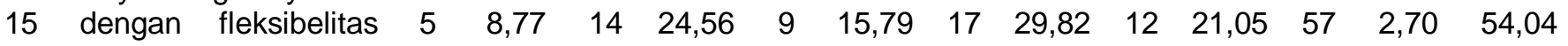
pekerjaan

Saya dapat

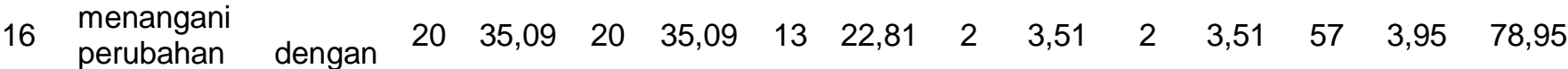
efektif dalam tim saya

Saya tidak

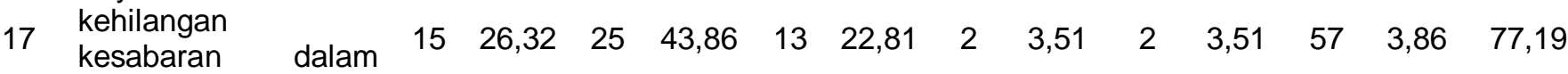
menghadapi kritik

Rata-rata $\begin{array}{lllllllllllll}15 & 26,32 & 22 & 38,30 & 12 & 20,18 & 5 & 8,77 & 4 & 6,43 & 57 & 3,69 & 73,86\end{array}$

Sumber: Hasil Olahan Data Primer, 2019

Variabel kinerja terdiri dari 3 dimensi dan 17 item pernyataan. Ratarata distribusi frekuensi variabel kinerja adalah 4,13 dari skala 5 dengan nilai TCR sebesar 73,80. Hal ini menunjukkan bahwa kinerja berada pada kategori tinggi. Dimensi dengan rata-rata tertinggi terdapat pada dimensi contextual performance yaitu 3,80 dengan TCR sebesar 76,07 dan dimensi dengan ratarata terendah terdapat pada dimensi task performance yaitu 3,59 dengan TCR sebesar 71,87.

Dimensi task performance, indikator dengan rata-rata tertinggi yaitu 3,7 dengan TCR sebesar 75,44 atau 28 responden menyatakan setuju atas pernyataan nomor satu, yaitu saya memiliki standar kinerja yang tinggi. Sedangkan nilai rata-rata terendah yaitu 3,47 dengan TCR sebesar 69,47 atau 25 responden menyatakan netral atas pernyataan nomor 3 , yaitu saya bersemangat dalam bekerja. Dimensi contextual performance, indikator dengan rata-rata tertinggi yaitu 3,95 dengan TCR sebesar 78,95 atau 29 responden menyatakan setuju dengan nomor 8 , yaitu 
ISSN 1412-2936

EISSN 2549-7308

saya menyampaikan simpati dan empati kepada karyawan yang sedang mengalami kesulitan. Sedangkan nilai rata-rata terendah yaitu 3,63 dengan TCR sebesar 72,63 atau 18 responden menyatakan netral terhadap pernyataan nomor 7 , yaitu saya biasanya memberikan bantuan kepada rekan kerja ketika diminta atau dibutuhkan. Dimensi adaptive performance, indikator dengan rata-rata tertinggi yaitu 4,02 dengan TCR sebesar 80,35 atau 29 responden menjawab setuju untuk pernyataaan nomor 12 , yaitu saya memiliki kecerdasan mobilitas kolektif yang baik dalam bekerja dengan tim. Sedangkan nilai rata-rata terendah yaitu 2,70 dengan TCR sebesar 54,04 atau 17 responden menyatakan tidak setuju dengan pernyataan nomor
15, yaitu saya sangat nyaman dengan fleksibelitas pekerjaan saya.

\subsubsection{Deskripsi Organizational Citizenship Behavior (OCB)}

Dalam penelitian ini Organizational Citizenship Behavior (OCB) merupakan variabel moderasi yang menghubungkan antara variabel bebas dengan variabel terikat. Organizational Citizenship Behavior (OCB) terdiri dari lima dimensi yaitu dimensi Conscientious dengan 5 item pernyataan dimensi Sportmanship dengan 4 pernyataan, dimensi Civic virtue dengan 5 pernyataan, dimensi Courtesy dengan 2 pernyataan, dan Altruism dengan 5 pernyataan. Jadi jumlah item pernyataan untuk variabel Organizational Citizenship Behavior (OCB) ada 21 pernyataan dengan lima dimensi tersebut.

Tabel 5. Deskripsi Variabel Organizational Citizenship Behavior (OCB)

\begin{tabular}{|c|c|c|c|c|c|c|c|c|c|c|c|c|c|c|}
\hline \multirow[t]{2}{*}{ No. } & \multirow[t]{2}{*}{ Item } & \multicolumn{2}{|c|}{ SS } & \multicolumn{2}{|c|}{$\mathbf{S}$} & \multicolumn{2}{|c|}{$\mathbf{N}$} & \multicolumn{2}{|c|}{ TS } & \multicolumn{2}{|c|}{ STS } & \multirow[t]{2}{*}{$\mathbf{N}$} & \multirow[t]{2}{*}{ Mean } & \multirow[t]{2}{*}{ TCR } \\
\hline & & $\mathbf{F i}$ & $\%$ & $\mathbf{F i}$ & $\%$ & $\mathbf{F i}$ & $\%$ & $\mathbf{F i}$ & $\%$ & $\mathbf{F i}$ & $\%$ & & & \\
\hline \multicolumn{15}{|c|}{ Sportmanship } \\
\hline 1 & $\begin{array}{l}\text { Saya sering komplen } \\
\text { tentang hal-hal yang } \\
\text { tidak terlalu penting }\end{array}$ & 16 & 28,07 & 27 & 47,37 & 9 & 15,79 & 4 & 7,02 & 1 & 1,75 & 57 & 3,93 & 78,60 \\
\hline 2 & $\begin{array}{l}\text { Saya selalu fokus } \\
\text { pada apa yang salah } \\
\text { dibandingkan melihat } \\
\text { sisi positifnya }\end{array}$ & 14 & 24,56 & 26 & 45,61 & 13 & 22,81 & 2 & 3,51 & 2 & 3,51 & 57 & 3,84 & 76,84 \\
\hline 3 & $\begin{array}{l}\text { Saya cenderung } \\
\text { cemas terhadap hal- } \\
\text { hal yang tidak perlu }\end{array}$ & 14 & 24,56 & 24 & 42,11 & 14 & 24,56 & 3 & 5,26 & 2 & 3,51 & 57 & 3,79 & 75,79 \\
\hline 4 & $\begin{array}{l}\text { Saya selalu } \\
\text { mengalami kesulitan } \\
\text { terhadap apa yang } \\
\text { sekolah lakukan }\end{array}$ & 14 & 24,56 & 21 & 36,84 & 15 & 26,32 & 5 & 8,77 & 2 & 3,51 & 57 & 3,70 & 74,04 \\
\hline & Rata-Rata & 10 & 25,44 & 16,3 & 42,98 & 9 & 22,37 & 2 & 6,14 & 1,2 & 3,07 & 38 & 3,82 & 76,32 \\
\hline \multicolumn{15}{|c|}{ conscientious } \\
\hline 5 & $\begin{array}{lr}\text { Saya } & \text { datang } \\
\text { ketempat } & \text { kerja } \\
\text { melebihi } & \text { kewajiban } \\
\text { saya } & \\
\end{array}$ & 13 & 22,81 & 22 & 38,60 & 15 & 26,32 & 5 & 8,77 & 2 & 3,51 & 57 & 3,68 & 73,68 \\
\hline 6 & $\begin{array}{ll}\text { Saya } & \text { tidak } \\
\text { mengambil } & \text { libur } \\
\text { tambahan } & \end{array}$ & 16 & 28,07 & 26 & 45,61 & 12 & 21,05 & 3 & 5,26 & 0 & 0,00 & 57 & 3,96 & 79,30 \\
\hline 7 & $\begin{array}{lr}\text { Saya } & \text { mematuhi } \\
\text { peraturan sekolah } \\
\text { meskipun tidak ada } \\
\text { yang memperhatikan }\end{array}$ & 18 & 31,58 & 27 & 47,37 & 10 & 17,54 & 1 & 1,75 & 1 & 1,75 & 57 & 4,05 & 81,05 \\
\hline
\end{tabular}


ISSN 1412-2936

EISSN 2549-7308

\begin{tabular}{|c|c|c|c|c|c|c|c|c|c|c|c|c|c|c|}
\hline 8 & $\begin{array}{lr}\text { Saya } & \text { adalah } \\
\text { karyawan } & \text { yang } \\
\text { bersungguh-sungguh } \\
\text { dan } & \text { bertangung } \\
\text { jawab } & \\
& \end{array}$ & 5 & 8,77 & 51 & 89,47 & 1 & 1,75 & 0 & 0,00 & 0 & 0,00 & 57 & 4,07 & 81,40 \\
\hline 9 & $\begin{array}{ll}\text { saya percaya } & \text { bahwa } \\
\text { bekerja } & \text { jujur } \\
\text { dapatakan } & \\
\text { mendapatkan } & \\
\text { bayaran } & \text { yang } \\
\text { setimpal } & \\
\end{array}$ & 15 & 26,32 & 18 & 31,58 & 19 & 33,33 & 4 & 7,02 & 1 & 1,75 & 57 & 3,74 & 74,74 \\
\hline & Rata-Rata & 20 & 24,22 & 40,1 & 48,65 & 16 & 19,74 & 4 & 5,13 & 1,9 & 2,26 & 82 & 3,87 & 77,49 \\
\hline \multicolumn{15}{|c|}{ Civic Vertue } \\
\hline 10 & $\begin{array}{l}\text { Saya adalah orang } \\
\text { yang suka mencari } \\
\text { perhatian }\end{array}$ & $\begin{array}{l}1 \\
2\end{array}$ & 21,05 & 27 & $\begin{array}{c}47,3 \\
7\end{array}$ & 15 & $\begin{array}{c}26,3 \\
2\end{array}$ & 2 & 3,51 & 1 & 1,75 & 57 & 3,82 & 76,49 \\
\hline 11 & $\begin{array}{l}\text { Saya menghadiri } \\
\text { rapat yang tidak } \\
\text { diwajibkan, tetapi } \\
\text { mempertimbangkan } \\
\text { seberapa penting } \\
\text { rapat tersebut }\end{array}$ & 8 & 14,04 & 24 & 42,11 & 21 & $\begin{array}{c}36,8 \\
4\end{array}$ & 2 & 3,51 & 2 & 3,51 & 57 & 3,60 & 71,93 \\
\hline 12 & $\begin{array}{l}\text { Saya memenuhi } \\
\text { fungsi-fungsi yang } \\
\text { tidak diharuskan } \\
\text { demi imej sekolah }\end{array}$ & 5 & 8,77 & 24 & 42,11 & 22 & $\begin{array}{c}38,6 \\
0\end{array}$ & 4 & 7,02 & 2 & 3,51 & 57 & 3,46 & 69,12 \\
\hline 13 & $\begin{array}{l}\text { Saya menghargai } \\
\text { perubahan dalam } \\
\text { sekolah }\end{array}$ & $\begin{array}{l}1 \\
0\end{array}$ & 17,54 & 20 & $\begin{array}{c}35,0 \\
9\end{array}$ & 23 & $\begin{array}{c}40,3 \\
5\end{array}$ & 3 & 5,26 & 1 & 1,75 & 57 & 3,61 & 72,28 \\
\hline 14 & $\begin{array}{l}\text { Saya membaca dan } \\
\text { mengikuti } \\
\text { pengumuman si } \\
\text { sekolah, memo dan } \\
\text { lain-lain }\end{array}$ & 6 & 10,53 & 26 & $\begin{array}{c}45,6 \\
1\end{array}$ & 20 & $\begin{array}{c}35,0 \\
9\end{array}$ & 4 & 7,02 & 1 & 1,75 & 57 & 3,56 & 71,23 \\
\hline & Rata-Rata & $\begin{array}{l}2 \\
8 \\
\end{array}$ & 20,59 & 61,1 & $\begin{array}{c}45,5 \\
5 \\
\end{array}$ & 35 & $\begin{array}{c}26,3 \\
3\end{array}$ & 7 & 5,29 & 3 & 2,24 & 134 & 3,77 & 75,39 \\
\hline \multicolumn{15}{|c|}{ Courtesy } \\
\hline 15 & $\begin{array}{lr}\text { Saya } & \text { selalu } \\
\text { menghindari masalah } \\
\text { dengan pekerjaan } \\
\text { yang lain }\end{array}$ & 8 & 14,04 & 29 & $\begin{array}{c}50,8 \\
8\end{array}$ & 16 & $\begin{array}{c}28,0 \\
7\end{array}$ & 3 & 5,26 & 1 & 1,75 & 57 & 3,70 & 74,04 \\
\hline 16 & $\begin{array}{lrr}\text { Saya } & \text { memahami } \\
\text { dampak } & \text { dari } & \text { aksi } \\
\text { saya terhadap } & \text { rekan } \\
\text { kerja } & & \\
\end{array}$ & $\begin{array}{l}1 \\
0\end{array}$ & 17,54 & 24 & 42,11 & 19 & $\begin{array}{c}33,3 \\
3\end{array}$ & 3 & 5,26 & 1 & 1,75 & 57 & 3,68 & 73,68 \\
\hline & Rata-Rata & $\begin{array}{l}2 \\
9\end{array}$ & 19,27 & 69,9 & $\begin{array}{c}46,5 \\
5\end{array}$ & 41 & $\begin{array}{c}27,1 \\
6\end{array}$ & 8 & 5,03 & 3 & 1,98 & 150 & 3,76 & 75,22 \\
\hline \multicolumn{15}{|c|}{ Altruism } \\
\hline 17 & \begin{tabular}{lrr} 
Saya & \multicolumn{2}{c}{ membantu } \\
rekan & kerja & yang \\
absen & & \\
\end{tabular} & $\begin{array}{l}1 \\
6\end{array}$ & 28,07 & 28 & $\begin{array}{c}49,1 \\
2\end{array}$ & 10 & $\begin{array}{c}17,5 \\
4\end{array}$ & 3 & 5,26 & 0 & 0,00 & 57 & 4,00 & 80,00 \\
\hline 18 & \begin{tabular}{lr} 
Saya & \multicolumn{2}{c}{ membantu } \\
rekan kerja yang \\
banyak tugas
\end{tabular} & $\begin{array}{l}1 \\
5\end{array}$ & 26,32 & 21 & $\begin{array}{c}36,8 \\
4\end{array}$ & 17 & $\begin{array}{c}29,8 \\
2\end{array}$ & 3 & 5,26 & 1 & 1,75 & 57 & 3,81 & 76,14 \\
\hline
\end{tabular}


ISSN 1412-2936

EISSN 2549-7308

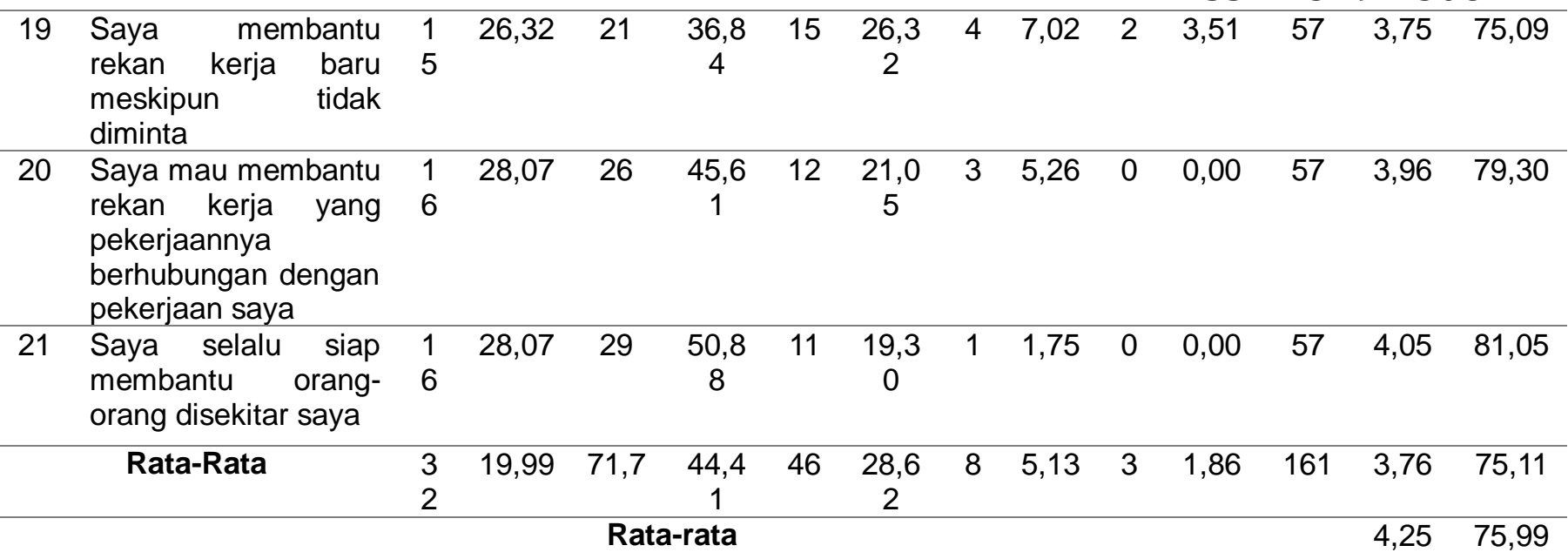

Sumber: Hasil Olahan Data Primer, 2019

Rata-rata tabel distribusi frekuensi variabelorganizational citizenship

behavior yaitu 4,25 dengan TCR sebesar 75,99. Hal ini menunjukkan bahwa organizational citizenship behavior berada pada kategori tinggi. Dimensi dengan rata-rata tertinggi terdapat pada dimensi consientius yaitu 4,07 dengan TCR sebesar 81,40 atau 51 responden menyatakan setuju dengan pernyataan nomor 8 bahwa saya adalah karyawan yang bersungguh-sungguh dan bertanggungjawab. Sedangkan dimensi dengan rata-rata terendah terdapat pada dimensi civic virtue yaitu 3,56 dengan TCR sebesar 71,23 atau 26 responden menyatakan bahwa saya membaca dan mengikuti pengumuman sekolah.

Dimensi sportmanship, indikator dengan rata-rata tertinggi yaitu 3,93 dengan TCR sebesar 78,60 yaitu saya tidak sering komplen terhadap hal-hal yang tidak terlalu penting. Sedangkan indikator dengan rata-rata terendah yaitu 3,70 dengan TCR sebesar 74,04 yaitu saya tidak mengalami kesulitan terhadap apa yang sekolah lakukan. Dimensi kedua adalah conscientius, indikator dengan rata-rata tertinggi adalah 4,07 dengan TCR sebesar 81,40 atau 51 responden menyatakan bahwa mereka adalah karyawan yang bersungguhsungguh dan bertanggung jawab. Sedangkan indikator dengan rata-rata terendah adalah 3,68 dengan TCR sebesar 73,68 atau 22 responden menyatakan bahwa saya datang ketempat kerja melebihi kewajiban saya. Dimensi ketiga adalah civic virtue, indikator dengan rata-rata tertinggi adalah 3,82 dengan TCR sebesar 76,49. Sedangkan indikator dengan rata-rata terendah adalah 3,46 dengan TCR sebesar 69,12. Selanjutnya adalah dimensi courtecy, indikator dengan ratarata tertinggi adalah 3,70 dengan TCR sebesar 74,04 atau 29 responden setuju dengan pertanyaan nomor 15 , yaitu saya selalu menghindari masalah dengan pekerjaan lain. Sedangkan indikator dengan nilai terendah yaitu 3,68 dengan TCR sebesar 75,23 atau 24 responden setuju bahwa saya memahami dampak dari aksi saya terhadap rekan kerja saya. Dimensi yang terakhir yaitu altruism, indikator dengan rata-rata tertinggi adalah 4,05 dengan TCR sebesar 81,05 atau 29 responden setuju bahwa saya membantu orang-orang disekitar saya. Sedangkan rata-rata terendah adalah 3,75 dengan TCR sebesar 75,09 atau 21 responden menyatakan setuju dengan pernyataan nomor 19, yaitu saya membantu rekan kerja baru meskipun tidak diminta.

\subsubsection{Deskripsi Kepuasan Kerja}

Dalam penelitian ini, kepuasan kerja merupakan variabel bebas yang mana terdiri dari beberapa dimensi yaitu dimensi nature of work dengan 3 item pernyataan, dimensi promotion dengan 3 item pernyataan dan dimensi supervision dengan 4 item pertanyaan dengan total 
ISSN 1412-2936

EISSN 2549-7308

10 item pernyataan.

Tabel 6. Deskripsi Variabel Kepuasan Kerja

\begin{tabular}{|c|c|c|c|c|c|c|c|c|c|c|c|c|c|c|}
\hline \multirow[t]{2}{*}{ No } & \multirow[t]{2}{*}{ Item } & \multicolumn{2}{|c|}{ SS } & \multicolumn{2}{|c|}{ S } & \multicolumn{2}{|r|}{$\mathrm{N}$} & \multicolumn{2}{|c|}{ TS } & \multicolumn{2}{|c|}{ STS } & \multirow[t]{2}{*}{$\mathrm{N}$} & \multirow[t]{2}{*}{ Mean } & \multirow[t]{2}{*}{ TCR } \\
\hline & & $\mathbf{F i}$ & $\%$ & $\mathbf{F i}$ & $\%$ & $\mathrm{Fi}$ & $\%$ & $\mathrm{Fi}$ & $\%$ & $\mathbf{F i}$ & $\%$ & & & \\
\hline \multicolumn{15}{|c|}{ Nature of Work } \\
\hline 1 & $\begin{array}{l}\text { Saya kadang-kadang } \\
\text { merasa pekerjaan } \\
\text { saya tidak bermakna }\end{array}$ & 16 & 28,07 & 24 & 42,11 & 10 & 17,54 & 5 & 8,77 & 2 & 3,51 & 57 & 3,82 & 76,49 \\
\hline 2 & $\begin{array}{l}\text { Saya merasa bangga } \\
\text { mengerjakan } \\
\text { pekerjaan saya }\end{array}$ & 15 & 26,32 & 28 & 49,12 & 8 & 14,04 & 4 & 7,02 & 2 & 3,51 & 57 & 3,88 & 77,54 \\
\hline 3 & $\begin{array}{ll}\text { Pekerjaan } & \text { saya } \\
\text { menyenangkan } & \end{array}$ & 14 & 24,56 & 27 & 47,37 & 12 & 21,05 & 2 & 3,51 & 2 & 3,51 & 57 & 3,86 & 77,19 \\
\hline & Rata-Rata & 20 & 26,10 & 30,5 & 40,10 & 14 & 18,97 & 7 & 8,99 & 4,4 & 5,85 & 76 & 3,72 & 74,32 \\
\hline \multicolumn{15}{|c|}{ Promotion } \\
\hline 4 & $\begin{array}{l}\text { Saya sedikit sekali } \\
\text { mendapatkan } \\
\text { kesempatan untuk } \\
\text { promosi jabatan di } \\
\text { pekerjaan saya }\end{array}$ & 14 & 24,56 & 25 & 43,86 & 13 & 22,81 & 3 & 5,26 & 2 & 3,51 & 57 & 3,81 & 76,14 \\
\hline 5 & $\begin{array}{lr}\text { Guru } & \text { yang } \\
\text { melakukan } & \\
\text { pekerjaannya dengan } \\
\text { baik mendapatkan } \\
\text { kesempatan yang } \\
\text { adil } \\
\text { dipromosikan untuk }\end{array}$ & 14 & 24,56 & 22 & 38,60 & 14 & 24,56 & 5 & 8,77 & 2 & 3,51 & 57 & 3,72 & 74,39 \\
\hline 6 & $\begin{array}{l}\text { Orang-orang } \\
\text { berusaha untuk terus } \\
\text { maju dan } \\
\text { berkembang secepat } \\
\text { mungkin }\end{array}$ & 14 & 24,56 & 19 & 33,33 & 18 & 31,58 & 4 & 7,02 & 2 & 3,51 & 57 & 3,68 & 73,68 \\
\hline & Rata-Rata & 18 & 25,56 & 29,2 & 41,98 & 15 & 21,39 & 5 & 7,14 & 2,7 & 3,93 & 70 & 3,78 & 75,62 \\
\hline \multicolumn{15}{|c|}{ Supervision } \\
\hline 7 & $\begin{array}{lr}\text { Pimpinan } & \text { saya } \\
\text { kompeten } & \text { dalam } \\
\text { melakukan } & \\
\text { pekerjaannya } & \end{array}$ & 13 & 22,81 & 23 & 40,35 & 14 & 24,56 & 5 & 8,77 & 2 & 3,51 & 57 & 3,70 & 74,04 \\
\hline 8 & $\begin{array}{l}\text { Pimpinan saya tidak } \\
\text { adil terhadap saya }\end{array}$ & 15 & 26,32 & 27 & 47,37 & 11 & 19,30 & 3 & 5,26 & 1 & 1,75 & 57 & 3,91 & 78,25 \\
\hline 9 & $\begin{array}{lr}\text { Pimpinan } & \text { saya } \\
\text { menunjukkan } & \\
\text { ketertarikan yang } \\
\text { sedikit terhadap } \\
\text { bawahannya }\end{array}$ & 18 & 31,58 & 28 & 49,12 & 9 & 15,79 & 1 & 1,75 & 1 & 1,75 & 57 & 4,07 & 81,40 \\
\hline 10 & $\begin{array}{l}\text { Saya menyukai } \\
\text { pemimpin saya }\end{array}$ & 5 & 8,77 & 52 & 91,23 & 0 & 0,00 & 0 & 0,00 & 0 & 0,00 & 57 & 4,09 & 81,75 \\
\hline & Rata-Rata & 29 & 24,54 & 55,8 & 46,77 & 23 & 19,33 & 7 & 6,12 & 3,9 & 3,24 & 119 & 3,83 & 76,65 \\
\hline & Zata & & & & & & & & & & & & 3,17 & 77,08 \\
\hline
\end{tabular}

Sumber : Hasil olahan data primer, 2019

Rata-rata distribusi frekuensi variabel kepuasan kerja adalah 3,17 dari skala 5 dengan nilai TCR sebesar 77,08.

Hal ini menunjukkan bahwa kepuasan kerja guru berada pada level tinggi. Dimensi dengan rata-rata tertinggi 
ISSN 1412-2936

EISSN 2549-7308

terdapat pada dimensi supervision yaitu sebesar 4,09 dengan TCR sebesar 81,75 atau 52 responden menyatakan jawaban setuju dengan pernyataan nomor 10 bahwa saya menyukai pimpinan saya dan dimensi dengan rata-rata terendah terdapat pada dimensi promotion yaitu 3,68 dengan TCR sebesar 73,68 atau 19 responden menyatakan setuju dengan pernyataan nomor 5 bahwa semua orang berusaha untuk maju dan berkembang secepat mungkin.

Dimensi nature of work, indikator dengan rata-rata tertinggi yaitu 3,88 dengan TCR sebesar 77,54 yaitu 28 responden menyakan setuju dengan pernyataan merasa bangga dengan pekerjaan mereka. Sedangkan indikator dengan rata-rata terendah adalah sebesar 3,82 dengan TCR sebesar 76,49 untuk pertanyaan nomor 1 yaitu 24 responden setuju bahwa saya merasa bermakna dengan pekerjaan saya. Selanjutnya dimensi promotion, dengan rata-rata tertinggi yaitu 3,81 dengan TCR sebesar 76,14 atau 14 responden sangat setuju dengan pernyataan bahwa saya sedikit sekali mendapatkan kesempatan untuk promosi jabatan. Sedangkan indikator dengan rata-rata terendah adalah 3,68 dengan TCR sebesar 73,68 atau 19 responden setuju dengan pertanyaan nomor 6 bahwa orang-orang berusaha keras untuk terus maju.

Dimensi yang terakhir adalah supervision, indikator dengan pernyataan nilai tertinggi adalah sebesar 4,09 dengan TCR sebesar 81,75 atau 52 responden menjawab setuju dengan pernyataan nomor 10 , yaitu saya menyukai pemimpin saya. Sedangkan indikator dengan ratarata terendah adalah sebesar 3,70 dengan TCR sebesar 74,04 atau 23 responden menyatakan setuju dengan pernyataan pimpinan saya kompeten dalam melakukan pekerjaannya.

\subsubsection{Deskripsi Komitmen Organisasional}

Dalam penelitian ini komitmen organisasional merupakan variabel bebas yang terdiri dari beberapa dimensi yaitu dimensi afektive dengan 4 item pernyataan, dimensi normative dengan 6 item pernyataan, dan dimensi afirmative dengan 5 item pernyataan. Jadi jumlah item pernyataan untuk variabel komitmen organisasional adalah 15 item pernyataan dengan tiga dimensi yang telah dijelaskan sebelumnya.

Tabel 7. Deskripsi Variabel Komitmen Organisasional

\begin{tabular}{|c|c|c|c|c|c|c|c|c|c|c|c|c|c|c|}
\hline \multirow[t]{2}{*}{ No. } & \multirow[t]{2}{*}{ Item } & \multicolumn{2}{|c|}{ SS } & \multicolumn{2}{|c|}{ S } & \multicolumn{2}{|r|}{$\mathrm{N}$} & \multicolumn{2}{|c|}{ TS } & \multicolumn{2}{|c|}{ STS } & \multirow[t]{2}{*}{$\mathrm{N}$} & \multirow[t]{2}{*}{ Mean } & \multirow[t]{2}{*}{ TCR } \\
\hline & & $\mathbf{F i}$ & $\%$ & $\mathbf{F i}$ & $\%$ & $\mathbf{F i}$ & $\%$ & $\mathrm{Fi}$ & $\%$ & $\mathbf{F i}$ & $\%$ & & & \\
\hline \multicolumn{15}{|l|}{ Afektif } \\
\hline 1 & $\begin{array}{l}\text { Saya akan senang } \\
\text { menghabiskan karir } \\
\text { saya disekolah ini }\end{array}$ & 11 & 19,30 & 28 & 49,12 & 14 & 24,56 & 2 & 3,51 & 2 & 3,51 & 57 & 3,77 & 75,44 \\
\hline 2 & $\begin{array}{l}\text { Saya benar-benar } \\
\text { merasa seolah-olah } \\
\text { masalah sekolah ini } \\
\text { adalah masalah } \\
\text { saya }\end{array}$ & 8 & 14,04 & 25 & 43,86 & 20 & 35,09 & 2 & 3,51 & 2 & 3,51 & 57 & 3,61 & 72,28 \\
\hline 3 & $\begin{array}{l}\text { Saya tidak merasa } \\
\text { seperti bagian dari } \\
\text { keluarga di sekolah } \\
\text { ini }\end{array}$ & 5 & 8,77 & 25 & 43,86 & 21 & 36,84 & 4 & 7,02 & 2 & 3,51 & 57 & 3,47 & 69,47 \\
\hline 4 & $\begin{array}{l}\text { Saya merasa tidak } \\
\text { terikat secara } \\
\text { emosional terhadap } \\
\text { sekolah ini }\end{array}$ & 9 & 15,79 & 21 & 36,84 & 22 & 38,60 & 3 & 5,26 & 2 & 3,51 & 57 & 3,56 & 71,23 \\
\hline & Rata-Rata & 38 & 22,76 & 78,1 & 46,57 & 36 & 21,51 & 10 & 5,88 & 5,5 & 3,29 & 168 & 3,80 & 75,93 \\
\hline
\end{tabular}


ISSN 1412-2936

EISSN 2549-7308

\begin{tabular}{|c|c|c|c|c|c|c|c|c|c|c|c|c|c|c|}
\hline \multicolumn{15}{|c|}{ Normative } \\
\hline 5 & $\begin{array}{l}\text { Saya tidak merasa } \\
\text { berkewajiban untuk } \\
\text { tetap disekolah ini }\end{array}$ & 5 & 8,77 & 27 & 47,37 & 19 & 33,33 & 4 & 7,02 & 2 & 3,51 & 57 & 3,51 & 70,18 \\
\hline 6 & $\begin{array}{l}\text { Bahkan jika } \\
\text { menguntungkan } \\
\text { bagi saya, saya } \\
\text { tidak merasa akan } \\
\text { pergi dari sekolah } \\
\text { ini }\end{array}$ & 7 & 12,28 & 30 & 52,63 & 15 & 26,32 & 3 & 5,26 & 2 & 3,51 & 57 & 3,65 & 72,98 \\
\hline 7 & 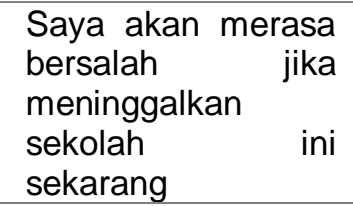 & 10 & 17,54 & 25 & 43,86 & 18 & 31,58 & 3 & 5,26 & 1 & 1,75 & 57 & 3,70 & 74,04 \\
\hline 8 & $\begin{array}{l}\text { Sekolah ini layak } \\
\text { mendapatkan } \\
\text { kesetiaan saya }\end{array}$ & 15 & 26,32 & 29 & 50,88 & 9 & 15,79 & 3 & 5,26 & 1 & 1,75 & 57 & 3,95 & 78,95 \\
\hline 9 & $\begin{array}{l}\text { Saya tidak akan } \\
\text { meninggalkan } \\
\text { sekolah ini } \\
\text { sekarang karena } \\
\text { saya merasa punya } \\
\text { kewajiban terhadap } \\
\text { sekolah ini }\end{array}$ & 15 & 26,32 & 21 & 36,84 & 16 & 28,07 & 3 & 5,26 & 2 & 3,51 & 57 & 3,77 & 75,44 \\
\hline 10 & $\begin{array}{l}\text { Saya berhutang } \\
\text { banyak terhadap } \\
\text { sekolah ini }\end{array}$ & 15 & 26,32 & 21 & 36,84 & 15 & 26,32 & 4 & 7,02 & 2 & 3,51 & 57 & 3,75 & 75,09 \\
\hline & Rata-Rata & 39 & 20,37 & 90,5 & 47,04 & 47 & 24,25 & 10 & 5,38 & 5,7 & 2,95 & 192 & 3,76 & 75,30 \\
\hline \multicolumn{15}{|c|}{ Afirmative } \\
\hline 11 & $\begin{array}{l}\text { Akan sulit bagi saya } \\
\text { untuk } \\
\text { meninggalkan } \\
\text { pekerjaan saya di } \\
\text { sekolah ini } \\
\text { sekarang, bahkan } \\
\text { jika saya } \\
\text { menginginkannya }\end{array}$ & 16 & 28,07 & 26 & 45,61 & 11 & 19,30 & 3 & 5,26 & 1 & 1,75 & 57 & 3,93 & 78,60 \\
\hline 12 & $\begin{array}{l}\text { Hidup saya akan } \\
\text { terganggu jika saya } \\
\text { meninggalkan } \\
\text { sekolah ini }\end{array}$ & 15 & 26,32 & 29 & 50,88 & 11 & 19,30 & 1 & 1,75 & 1 & 1,75 & 57 & 3,98 & 79,65 \\
\hline 13 & $\begin{array}{l}\text { Tetap berada di } \\
\text { sekolah ini adalah } \\
\text { kebutuhan yang } \\
\text { menjadi keinginan } \\
\text { bagi saya }\end{array}$ & 16 & 28,07 & 20 & 35,09 & 14 & 24,56 & 4 & 7,02 & 3 & 5,26 & 57 & 3,74 & 74,74 \\
\hline 14 & $\begin{array}{l}\text { Saya percaya saya } \\
\text { memiliki sedikit } \\
\text { pilihan untuk } \\
\text { mempertimbangkan } \\
\text { meninggalkan } \\
\text { sekolah ini }\end{array}$ & 20 & 35,09 & 23 & 40,35 & 10 & 17,54 & 4 & 7,02 & 0 & 0,00 & 57 & 4,04 & 80,70 \\
\hline
\end{tabular}


ISSN 1412-2936

EISSN 2549-7308

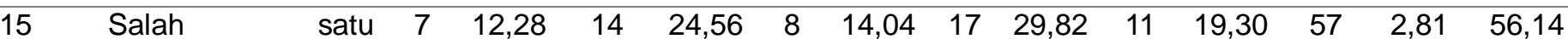

konsekuensi negatif

meninggalkan

pekerjaan disekolah

ini adalah bahwa

pergi akan

membutuhkan

pengorbanan

pribadi yang besar

Rata-Rata

$\begin{array}{llllllllllll}42 & 20,69 & 88,8 & 43,83 & 51 & 25,16 & 13 & 6,60 & 7,5 & 3,72 & 203 & 3,71\end{array}$

74,23

Rata Rata

3,69

73,66

Sumber: Pengolahan data primer, 2019

Rata-rata distribusi frekuesi

variabel komitmen organisasional 3,86

dengan TCR sebesar 73,66. Hal ini

menunjukkan bahwa komitmen

organisasional berada pada kategori

tinggi. Dimensi dengan rata-rata tertinggi

adalah dimensi afirmative yaitu 4,04

dengan TCR sebesar 80,70 atau 23

responden menyatakan setuju dengan

pernyataan bahwa saya memiliki sedikit

pilihan mempertimbangkan untuk

meninggalkan sekolah ini dan dimensi

dengan rata-rata terendah adalah dimensi

afirmative dengan rata-rata 2,81 yaitu dengan TCR sebesar 54,16.

Dimensi afektif, indikator dengan rata-rata tertinggi yaitu 3,77 dengan TCR sebersar 75,44 atau 28 responden menyatakan setuju dengan pertanyaan nomor 1, yaitu saya akan senang menghabiskan waktu saya disekolah ini. Sedangkan indikator dengan rata-rata terendah yaitu 3,47 dengan TCR sebesar 69,47 atau 25 responden menyatakan saya merasa menjadi seperti bagian dari keluarga disekolah ini. Selanjutnya dimensi normative, indikator dengan ratarata tertinggi yaitu 3,95 dengan TCR sebesar 78,95 atau 29 responden menyatakan setuju dengan pernyataan nomor 8 bahwa sekolah ini layak mendapatkan kesetiaan dari saya. Sedangkan indikator dengan nilai ratarata terendah yaitu 3,51 dengan TCR sebesar 70,18 atau 27 responden menyatakan setuju bahwa saya merasa tidak berkewajiban meninggalkan sekolah ini. Dimensi yang terakhir adalah afirmative, indikator dengan nilai rata-rata tertinggi yaitu 4,04 dengan TCR sebesar

80,70 atau 23 responden menyatakan setuju dengan pertanyaan nomor 14, yaitu saya percaya bahwa saya memiliki sedikit pilihan untuk meninggalkan sekolah ini. Sedangkan indikator dengan rata-rata terendah yaitu 2,81 dengan TCR sebesar 56,14 atau 17 responden menyatakan tidak setuju dengan pernyataan nomor 15 , yaitu salah satu konsekuensi negatif meninggalkan sekolah ini adalah bahwa itu akan membutuhkan pengorbanan pribadi yang besar.

\subsubsection{PengujianMeasurement Model \\ 3.1.4.1 Uji Individual Item Reliability}

Pengujian ini dilakukan untuk melihat indikator mana yang baik digunakan untuk mengukur masingmasing variabel dengan kata lain untuk melihat reliabilitas untuk setiap indikator. Nilai factor loading yang tinggi menunjukkan bahwa indikator tersebut memang menjelaskan variabel yang diukurnya. Indikator yang memiliki nilai factor loading antara 0,5-0,6 dapat diterima (Yamin dan kurniawan, 2011 : 202) dan sebaliknya jika dibawah nilai tersebut maka akan dihilangkan dalam model saat melakukan pengujian ini.

Nilai outer loading awal pada variabel kinerja (KK), Organizational Citizenship Behavior (OCB), Kepuasan Kerja (JS), dan Komitmen Organizational (KO) dapat dilihat pada tabel 4.7dibawah ini. Hasil pengolahan data dengan menggunakan SmartPLS 3.0 menghasilkan outer loading untuk setiap indikator dari masing-masing variabel yang diteliti. Hasil nilai outer loading menunjukkan bahwa beberapa indikator 
ISSN 1412-2936

EISSN 2549-7308

yang mengukur variabel kinerja, organizational citizenship behavior, kepuasan kerja dan komitmen organisasional mempunyai nilai dibawah 0,5 akan dihilangkan dalam model.

Dari hasil analisis data PLS diketahui bahwa indikator yang dinyatakan tidak valid karena nilai outer loading indikator dibawah 0,50 terdiri dari variable kinerja (pernyataan nomor 15), Variabel kepuasan kerja (pernyataan nomor 10), Variabel komitmen organisasional (pernyataan nomor 13, 14 dan 15), dan Variabel organizational citizenship behavior (pernyataan nomor 9 , 15, 16 dan 21). Indikator pernyataan yang tidak valid dihilangkan dalam model, kemudian model kembali di calculate hingga semua indikator pada variabel penelitian tersebut valid yang mana nilai outer loadingnya berada diatas 0,50 .

\subsubsection{Uji Internal Consistency}

Untuk mengetahui sejauh mana alat pengukuran tersebut mempunyai akurasi dan ketepatan pengukuran yang konsisten dari waktu ke waktu maka dilakukan uji reliabilitas. Reliabilitas instrumen dalam penelitian ini diukur dengan dua kriteria yaitu nilai composite reliability dan cronbachs alpha. Penggunaa cronbachs alpha untuk menguji reliabilitas variabel akan memberikan nilai yang lebih rendah sehingga disarankan untuk menggunakan composite reliability (Haryono,2017: 407). Suatu konstruk dikatakan reliabel jika nilai composite reliability diatas 0,70 (Ghozali, 2015: 230).

Tabel 8. Hasil Uji Reliabilitas

\begin{tabular}{lc}
\hline & Composite Reliability \\
\hline Kepuasan Kerja & 0.961 \\
\hline Kinerja Guru & 0.944 \\
\hline Komitmen Organisasi & 0.939 \\
\hline Organizational Citizenship Behavior & 0.955
\end{tabular}

Sumber: Hasil Olahan Data PLS, 2019

Dari tabel terlihat semua variabel mempunyai nilai composite reliability diatas 0,70 . Oleh karena itu, indikator yang digunakan dalam variabel penelitian ini dikatakan reliabel.

\subsubsection{Uji Discriminant Validity}

Pengujian ini dilakukan untuk melihat seberapa besar perbedaan antar variabel. Nilai yang dilihat dalam pengujian ini adalah nilai average variance extracted (AVE) yang diperoleh sebagai hasil estimasi dimana nilainya harus $>0,50$.

Tabel 9. Concruct Validity

\begin{tabular}{lc}
\hline & $\begin{array}{c}\text { Average Variance Extracted } \\
\text { (AVE) }\end{array}$ \\
\hline Kepuasan Kerja & 0.734 \\
\hline Kinerja Guru & 0.516 \\
\hline Komitmen Organisasi & 0.567 \\
\hline Organizational Citizenship behavior & 0.561
\end{tabular}

Sumber: Hasil Olahan Data PLS, 2019

Nilai AVE semua variabel telah memenuhi syarat dimana semua variable memiliki nilai AVE diatas 0,50. Selanjutnya syarat yang harus dipenuhi adalah nilai akar kuadrat dari AVE setiap variabel harus lebih besar dari nilai

korelasi dengan variabel lainnya. Jika nilai akar kuadrad AVE setiap konstruk lebih besar daripada nilai korelasi antara konstruk dengan konstruk lainnya dalam model maka dikatakan memiliki nilai discriminanrt validity yang baik.

Tabel 10. Nilai Discriminant Validity

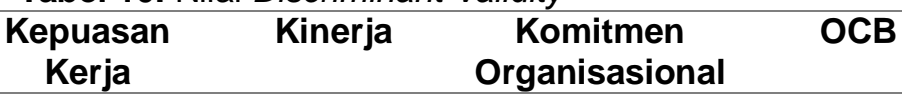


ISSN 1412-2936

EISSN 2549-7308

\begin{tabular}{lllll} 
Kepuasan Kerja & 0.857 & & & \\
\hline Kinerja Guru & 0.925 & 0.718 & & \\
\hline $\begin{array}{l}\text { Komitmen } \\
\text { Organisasional }\end{array}$ & 0.904 & 0.982 & 0.753 & \\
\hline OCB & 0.928 & 0.871 & 0.879 & 0.749
\end{tabular}

Sumber: Hasil Olahan Data PLS, 2019

Nilai perbandingan dari nilai akar

AVE memperlihatkan bahwa masingmasing dari nilai tersebut lebih besar dibandingkan dengan korelasi antar variabel lainnya. Sehingga dapat disimpulkan bahwa seluruh variable laten memiliki discriminant validity yang baik.

3.1.5 Evaluasi Structural Model

Tabel 11. Evaluasi Structural Model

Evaluasi Strutural Model dari model pengukuran indikator refleksif dengan menggunakan $\mathrm{R}$ square. Perubahan nilai $\mathrm{R}$ square dapat digunakan untuk menilai pengaruh variabel laten independen tertentu terhadap variabel laten dependen apakah mempunyai pengaruh yang substantif.

\begin{tabular}{ll}
\hline \multicolumn{2}{c}{ R Square } \\
\hline Kinerja Guru & 0.974 \\
\hline Organizational citizenship behavior & 0.870
\end{tabular}

Sumber: Hasil Olahan Data PLS, 2019

Nilai $R$ square untuk variable kinerja guru yaitu 0,974 yang dapat diinterpretasikan bahwa variable kinerja dipengaruhi oleh organizational citizenship behavior 97,4 \% sedangkan sisanya yaitu $2,6 \%$ dijelaskan oleh variabel lain diluar penelitian ini. Nilai $R$ square untuk variabel Organizational Citizenship Behavior (OCB) yaitu 0,870 yang dapat diinterpretasikan bahwa variabel organizational citizenship behavior dipengaruhi oleh variabel kepuasan kerja dan komitmen organisasi sebesar $87,0 \%$ sedangkan sisanya 23,0 $\%$ dijelaskan oleh variabel lain diluar penelitian.

\subsubsection{Analisis Pengaruh Lansung dan Tidak Langsung}

Untuk melakukan pengujian hipotesis, dimana nilai $\mathrm{t}$ ( $\mathrm{t}$-value) yang dihasilkan dengan menjalankan algoritma bootstrapping pada SmartPLS digunakan untuk menentukan diterima atau tidaknya hipotesis yang diajukan. Hipotesis menggunakan two-tailed test, rule of thumb tingkat signifikan $10 \%$ (t statistic $1,65)$, tingkat signifikansi $5 \%$ (t-statistik 1,96) dan tingkat signifikansi $1 \% \quad(\mathrm{t}$ statistik 2,75). Jadi hipotesis pertama diterima pada saat tingkat signifikansi lebih kecil dari 0,05 atau t-value melebihi nilai kritisnya yaitu 1,96 (Hair et al.,2014).

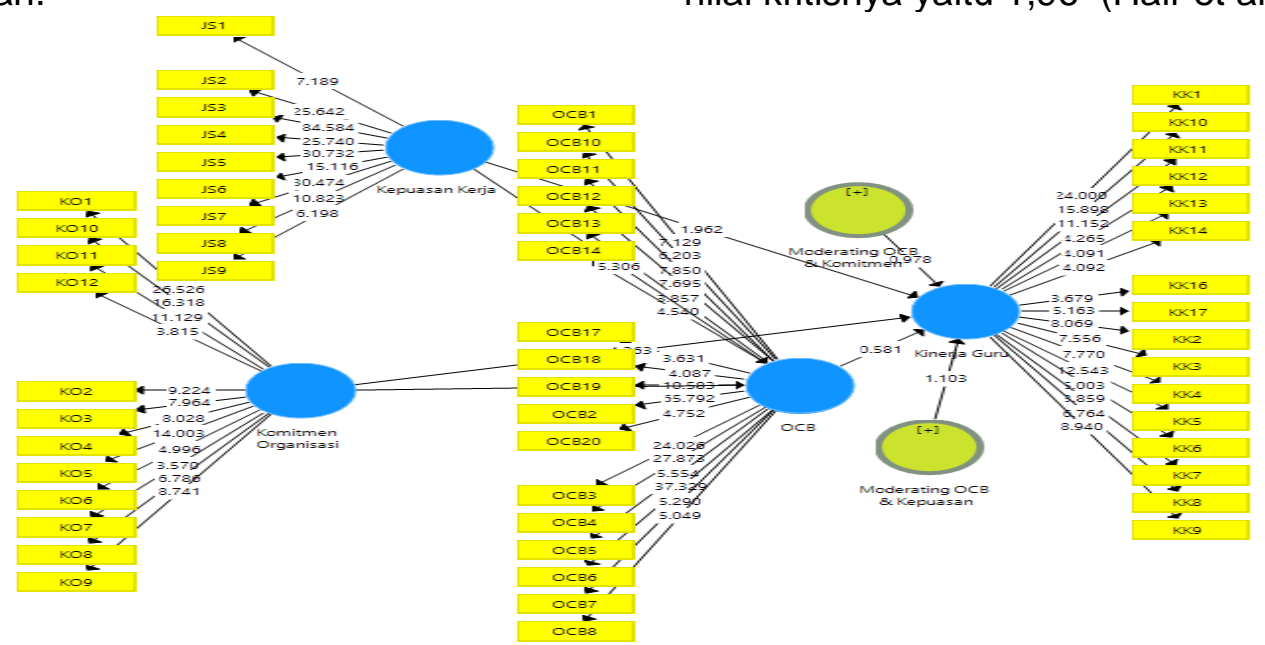

Sumber : Hasil Olahan Data PLS, 2019 
ISSN 1412-2936

EISSN 2549-7308

Gambar 1. Hasil bootstrapping

Nilai pengaruh langsung dan tidak langsung dari gambar diatas dapat dilihat pada tabel path coefficient dibawah ini.

Tabel 12. Path Coefficient

\begin{tabular}{|c|c|c|c|c|c|}
\hline & $\begin{array}{c}\text { Original } \\
\text { Sample } \\
\text { (0) }\end{array}$ & $\begin{array}{l}\text { Sample } \\
\text { Mean (M) }\end{array}$ & $\begin{array}{c}\text { Standard } \\
\text { Deviation } \\
\text { (STDEV) }\end{array}$ & $\begin{array}{l}\text { T Statistics } \\
\text { (|O/STDEV } \mid)\end{array}$ & $\begin{array}{c}\mathbf{P} \\
\text { Values }\end{array}$ \\
\hline Kepuasan Kerja -> Kinerja Guru & 0.380 & 0.435 & 0.190 & 1.999 & 0.046 \\
\hline Kepuasan Kerja -> OCB_ & 0.733 & 0.734 & 0.140 & 5.236 & 0.000 \\
\hline $\begin{array}{l}\text { Komitmen Organisasi }->\text { Kinerja } \\
\text { Guru }\end{array}$ & 0.779 & 0.845 & 0.173 & 4.509 & 0.000 \\
\hline Komitmen Organisasi -> OCB_ & 0.216 & 0.236 & 0.170 & 1.275 & 0.203 \\
\hline $\begin{array}{l}\text { Moderating OCB \& Kepuasan -> } \\
\text { Kinerja Guru }\end{array}$ & -0.119 & -0.102 & 0.109 & 1.095 & 0.274 \\
\hline $\begin{array}{l}\text { Moderating OCB \& Komitmen -> } \\
\text { Kinerja Guru }\end{array}$ & 0.099 & 0.090 & 0.103 & 0.967 & 0.334 \\
\hline OCB_-> Kinerja Guru & -0.171 & -0.280 & 0.280 & 0.610 & 0.542 \\
\hline
\end{tabular}

Sumber: Hasil Olahan Data PLS, 2019

Dari hasil path coefficient diatas

dapat dilihat nilai original sample dan $\mathrm{p}$ values atau $\mathrm{t}$ statistik yang digunakan sebagai acuan untuk menerima hipotesis atau menolak hipotesis. Hipotesis dapat diterima jika nilai t statistic $>$ t tabel atau $p$ value $<0,05$. Hipotesis pertama yaitu kepuasan kerja berpengaruh positif dan signifikan terhadap kinerja guru di SMAN 1 Tilatang Kamang. Pada tabel 4.13 diatas dapat dilihat bahwa nilai dari original sampel sebesar 0,380 dan $p$ values sebesar 0,046 $<0,05$. Dengan demikian hipotesis pertama diterima.

Hipotesis kedua yaitu komitmen organisasional berpengaruh positif dan signifikan terhadap kinerja guru di SMAN 1 Tilatang Kamang. Dari tabel 4.13 diatas dapat dilihat bahwa nilai original sampel sebesar 0,733 dan p 2 sebesar 0,00< 0,05 . Dengan demikian hipotesis kedua diterima.

Hipotesis ketiga yaitu organizational citizenship behavior memoderasi pengaruh kepuasan kerja terhadap kinerja guru di SMAN 1 Tilatang Kamang. Hasil nilai p-value 0,334 >0,05. Artinya adalah tidak terjadi efek moderasi. Hipotesis keempat yaitu organizational citizenship behavior memoderasi pengaruh komitmen organisasional terhadap kinerja guru di SMAN 1 Tilatang Kamang. Hasil nilai $p$ value sebesar 0,542 >0,05. Artinya adalah organizational citizenship behavior tidak terjadi efek moderasi.

\subsection{Pembahasan Hasil Penelitian \\ 3.2.1 Pengaruh Kepuasan Kerja terhadap Kinerja guru di SMAN 1Tilatang Kamang}

Berdasarkan uji hipotesis dalam penelitian ini ditemukan bahwa kepuasan kerja berpengaruh positif dan signifikan terhadap kinerja guru di SMAN 1 Tilatang Kamang. Artinya adalah tingginya tingkat kepuasan kerja seoarang karyawan maka akan memicu meningkatnya kinerja karyawan ditempat mereka bekerja. Hal ini sesuai dengan penelitian yang dilakukan oleh Buyukse (2014), Weerakody (2016), Inuwa (2016) bahwa terdapat hubungan positif siginifikan antara kepuasan kerja dan kinerja.

Dimensi supervision dengan indikator tertinggi adalah saya menyukai pimpinan saya dengan nilai mean sebesar 4,09 dan TCR sebesar 81,75 dengan kategori sangat tinggi. Artinya adalah bahwa gaya kepemimpinan dari kepala sekolah, maupun wakil-wakil kepala sekolah merupakan indikator kepuasan dari guru-guru di SMAN 1. Selain itu, jika dilihat dari dimensi nature of work dengan indikasi indikator tertinggi adalah saya merasa bangga melakukan 
ISSN 1412-2936

EISSN 2549-7308

pekerjaan saya dengan nilai mean sebesar 3,88 dan TCR sebesar 77,54 dengan kategori tinggi.

Kaliski dan Ndule (2016) menyatakan bahwa kepuasan kerja dapat dianggap sebagai capaian dan seberapa sukses seorang karyawan dalam pekerjaannya yang dapat memiliki hubungan langsung terhadap kinerjanya. Di SMAN 1 Tilatang Kamang,pengaruh langsung yang dapat dilihat yaitu rata-rata kepuasan kerja yang tergolong tinggi dengan rata-rata sebesar 3,17 dengan TCR sebesar 63,6 dan rata-rata kinerja sebesar 4,13 dengan nilai TCR sebesar 82,51 . Hal ini juga dapat dilihat dengan capaian yang telah dicapai oleh SMAN 1 Tilatang Kamang dalam 3 tahun terakhir dimana terpilih sebagai sekolah model enterpreneurship, sekolah Adiwiyata tingkat nasional, sekolah sehat tingkat provinsi. Disamping itu, prestasi dibidang adademik siswa yang dapat dilihat melalui jumlah siswa lulusan SMAN 1 Tilatang Kamang yang diterima di tingkat perguruan tinggi sebanyak 108 siswa dari 166 lulusan pada tahun 2018.

\subsubsection{Pengaruh Komitmen Organisasional terhadap Kinerja guru di SMAN 1Tilatang Kamang}

Berdasarkan uji hipotesis dalam penelitian ini ditemukan bahwa komitmen organisasional berpengaruh positif dan signifikan terhadap kinerja guru di SMAN 1 Tilatang Kamang. Hal ini menunjukkan bahwa semakin tinggi komitmen organisasional maka akan semakin tinggi kinerja para guru di SMAN 1 Tilatang Kamang. Hal ini sejalan dengan penelitian Irefan (2013) dan Bektas (2018) dimana dalam hasil penelitiannya ditemukan bahwa komitmen organisasional memiliki hubungan positif signifikan terhadap kinerja.

Berdasarkan hasil survei terlihat bahwa dominan guru setuju dengan jawaban rata-rata tertinggi sebesar 4,04 dengan TCR sebesar 80,70, yaitu saya percaya saya memiliki sedikit pilihan untuk mempertimbangkan meninggalkan sekolah ini. Dari data demografi terlihat dimana $98,2 \%$ guru telah mengajar di SMAN 1 Tilatang Kamang selama lebih dari 5 tahun. Selain itu, pertimbangan karena telah menikah dan berkeluarga juga merupakan faktor yang menjadi pertimbangan guru di SMAN 1 Tilatang Kamang dimana 98,2 \% guru telah menikah dan tentunya memutuskan untuk pindah akan membutuhkan pengorbanan yang besar dari guru itu sendiri.

\subsubsection{Organizational Citizenship Behavior (OCB) memoderasi hubungan antara Kepuasan Kerja dengan Kinerja guru di SMAN 1 Tilatang Kamang \\ Berdasarkan uji hipotesis dalam} penelitian ini ditemukan bahwa organizational citizenship behavior tidak memoderasi kepuasan kerja terhadap kinerja di SMAN 1 Tilatang Kamang. Hal ini dapat diatikan sebagai antara kepuasan kerja dengan OCB adalah hal yang berbeda, dimana karyawan yang memiliki OCB yang tinggi, belum tentu mereka puas terhadap pekerjaannya. Begitupun sebaliknya, karyawan yang puas dengan pekerjaannya belum tentu memiliki OCB yang tinggioleh karena itu kombinasi antara kedua variabel ini tidak memberikan pengaruh yang signifikan terhadap kinerja.

Temuan ini tidak sejalan dengan penelitian Hakim (2013) dimana organizational citizenship behavior memoderasi hubungan antara kepuasan kerja dengan kinerja. Hal ini dipengaruhi oleh jenis pekerjaan itu sendiri, dimana sebagaimana diartikan organizational citizenship behavior menurut Organ (1998) adalah pekerjaan yang berhubungan dengan perilaku yang tidak mengikat, yang tidak berkaitan secara lansung dengan sistem formal reward dan secara keseluruhan meningkatkan keefektifan fungsi organisasi. Contoh penerapan OCB pada guru adalah adanya kegiatan belajar tambahan disiang hari bagi siswa, kegiatan gotong royong, dan perlombaan-perlombaan sekolah. Jadi pada dasarnya, meskipun tingkat OCB rendah, tidak mempengaruhi 
ISSN 1412-2936

kepuasan terhadap kinerja karena OCB lebih kepada tindakan sukarela dari guru tersebut.

\subsubsection{Organizational Citizenship Behavior (OCB) memoderasi hubungan antara Komitmen Organisasional dengan Kinerja guru di SMAN 1 Tilatang Kamang \\ Berdasarkan uji hipotesis dalam penelitian ini ditemukan bahwa organizational citizenship behavior tidak memoderasi hubungan komitmen organisasional dengan kinerja guru di SMAN 1 Tilatang Kamang. Temuan ini sejalan dengan penelitian Otto (2018) dimana organizational citizenship behavior tidak memoderasi pengaruh antara komitmen organisasional terhadap kinerja. Hal ini dapat diartikan karyawan yang memiliki OCB yang kuat tidak berpengaruh terhadap berkomitmennya kepada organisasi.Namun hasil penelitian ini tidak sejalan dengan penelitian Hakim (2013) dimana dalam penelitiannya hakim menemukan bahwa organizational citizenship behavior memoderasi pengaruh komitmen organisasional terhadap kinerja.}

\section{KESIMPULAN}

1. Berdasarkan hasil penelitian, hipotesis pertama diterima, dimana hasil penelitian menunjukkan bahwa kepuasan kerja berpengaruh positif dan signifikan terhadap kinerja guru di SMAN 1 Tilatang Kamang. Sehingga dapat disimpulkan bahwa semakin tinggi tingkat kepuasan kerja guru maka akan semakin tinggi kinerja seorang guru di SMAN 1 Tilatang Kamang.

2. Berdasarkan hasil penelitian, hipotesis kedua diterima, dimana hasil penelitian menunjukkan bahwa komitmen organisasional berpengaruh positif dan signifikan terhadap kinerja guru di SMAN 1 Tilatang Kamang. Sehingga dapat disimpulkan, semakin tinggi komitmen organisasional guru
EISSN 2549-7308

terhadap sekolah maka akan semakin tinggi kinerja seorang guru di SMAN 1 Tilatang Kamang.

3. Berdasarkan hasil penelitian, hipotesis ketiga, dimana organizational citizenship behavior tidak memoderasi kepuasan kerja terhadap kinerja guru di SMAN 1 Tilatang Kamang.

4. Berdasarkan hasil penelitian, hipotesis keempat, dimana organizational citizenship behavior tidak memoderasi komitmen organisasional dengan kinerja guru di SMAN 1 Tilatang Kamang.

\section{DAFTAR PUSTAKA}

BektasVeli, N. (2018). The Relationship Between Organisational Commitment and Work Performance: A Case of Industrial Enterprises. Journal of Economic and Social Development (JESD). Vol. 5, No. 1, March 2018.

Buyukbese, T dan Sezer, B. (2014).The effect of job satisfaction on job performance and occupotional commitment.ISSN 2278-5612

Bogler, R. \& Somith, A. (2005). Organizational Citizenship Behavior in School: How Does it Relate to Participation in Decision Making?. Journal of Educational Administration, Vol. 43 Issue: 5, pp.420-438.

WWW.

Emeraldinsight.com

Ghozali, Imam. (2011). Aplikasian Analisis Multivariate dengan Program SPSS.Semarang: UNDIP.

Gibson. (2002). OrganisasiPerilakuStruktur Proses (TerjemahanEdisiKelima).Jakarta: Erlangga.

Hakim, W. Dan Fernandes, A. (2017). Moderation effect of Organizational Citizenship Behavior on the 
ISSN 1412-2936

EISSN 2549-7308

Performance of Lecturers. Journal of Organizational Change Management \& Marketing, 7-2, 151Management, Vol.30 Issue: 7, pp. 160

1136-1148. www.emeraldinsight.

Irefan, Peace dan Mechanic, M (2013).Effect of employee commitment on organizational performance in Coca Cola Nigeria Limited, Mauduguri, Borno State.IOSR Journal OfHumanities And Social Science (IOSR-JHSS). Volume 19, Issue 3, Ver. I (Mar. 2014), PP 33-41.

Inuwa, M (2016). Job Satisfaction and Employee Performance: An Empirical Approach. The Millennium University Journal; Vol. 1, No. 1; 2016 ISSN 2225-2533 Published by The Millennium University

Otto, R., Rita, M. et.al (2018). Moderating Effect of Organizational Citizenship Behavior on the effect of organizational Commitment, Transformational Leadership and work motovation on Employee Performance.

www.emeraldinsight.com

Sekaran, Uma (2011). Research Method for Business:Metodologi Penelitian untuk Bisnis. Edisi I dan II. Jakarta: SalembaEmpat.

Slamet, N. et.al (2013). The impact of organizatioanal climate on teacher's job performance. E-journal Educational research.

Weerakkody, W (2016). Impact of Job Satisfaction on Job Performance of Non Executive Employee with Reference to Kalutara District in Sri Lanka.

Zefeiti,SMBA\& Noor. aM. (2017). The influence of Organizational Commitment on Omani Public employee. Work Performance. International Review of 